\title{
DETERMINING FACTORS OF ACADEMIC SUCCESS OF FIRST YEAR BSc DIETETICS STUDENTS
}

\author{
A. Gresse* \\ https://orcid.org/0000-0003-2147-7812 \\ C. Stansbury* \\ ${ }^{*}$ Department of Human Nutrition and Dietetics \\ Nelson Mandela University (NMU) \\ Port Elizabeth, South Africa
}

\section{ABSTRACT}

It is broadly acknowledged that a host of factors influence the academic success of students, but there currently is a paucity of literature about this issue in the field of health sciences, and none in specifically Dietetics, in South Africa, and very little globally. This constitutes a significant knowledge gap in the field of higher education, as determining which factors are most important in facilitating the success of Dietetics students in a South African context, will make a significant contribution to understanding and assisting such students.

The aim of this article is to report on a study that identified the key factors of success of first year BSc Dietetics students at one South African university. The aim of the study was to inform the design of interventions that would improve the performance and throughput of these students. Quantitative analysis of success factors contained in the existing data of the university, qualitative focus group discussions on students' perceptions and a questionnaire with a qualitative and quantitative section on success factors were used.

In recruiting students for Dietetics, strict adherence to admission criteria is necessary and support should be given to students on an individual basis to ensure the highest quality of student intake and eventual output. This study showed that Dietetics students realised their own responsibility to ensure their academic success, but participants also provided important insights on what can be done by the staff, the department and university in order to improve the academic success. This information is useful to others in the higher education community and also in other programmes in health sciences. More research on the perception of staff regarding academic success factors is needed and various intervention strategies to improve success can then be investigated.

Keywords: Dietetics students, academic success, student perceptions

\section{INTRODUCTION}

Universities worldwide are placing the academic success of their students as a far greater priority (Mills et al. 2009) due to more people being at university than ever before (Swartz, 
2015). However, as York, Gibson and Rankin (2015) noted, academic success has no clear and distinct definition. Every student is unique and has his or her own learning style (Sarabi-Asiabar et al. 2015). In an Australian dietetics programme, it was, for example, found that dietetics students are intuitive and they prefer verbal explanations and global or holistic approaches, with practical and reasoning learning styles (Palermo et al. 2009; Williams, Brown, and Etherington 2012). There are various factors that can either prevent or promote academic success among university students. Some factors are dependent on the learner, such as inadequate study skills and lack of confidence, while others are dependent on the environment, for example, resources available at universities and the number of students in the class (Stebleton and Soria 2013). A diagramme to illustrate the definition of academic success by York et al. (2015) can be seen in Figure 1.

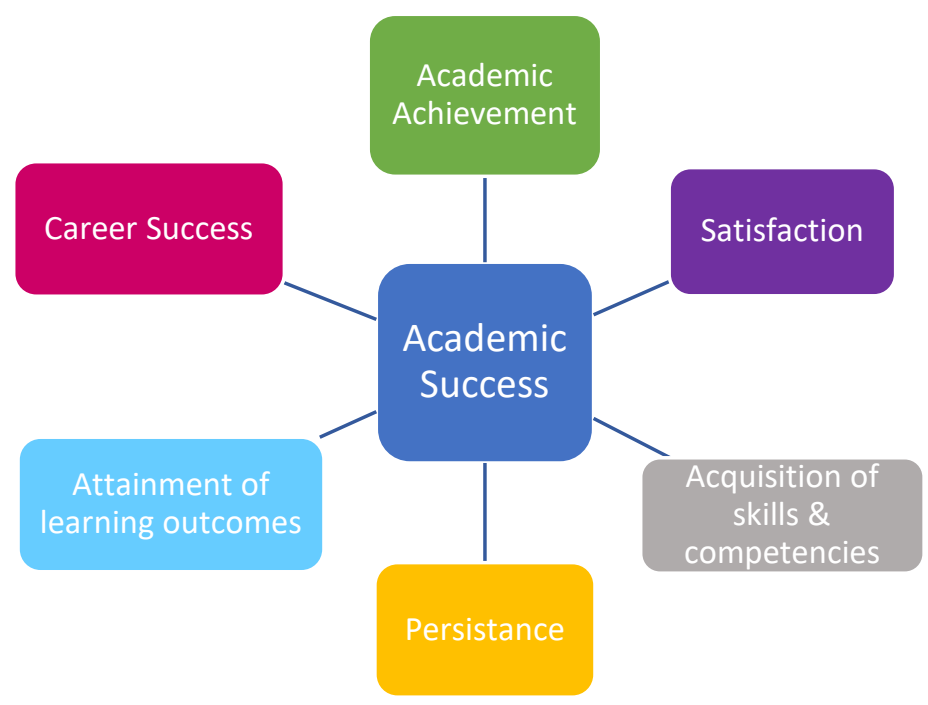

Figure 1: Factors that contribute to the definition of academic success (York et al. 2015, 2)

Though York et al. (2015) are writing from an American perspective, the situation is not different in South Africa. University student numbers in post-Apartheid democratic South Africa, have increased from 480000 in 1995 to over 980000 students in 2014, with over 80 per cent of the students being black and 54 per cent female. Yet, a South African review of higher education success over the last 25 years has shown that only 22 per cent of students at higher education institutions completed a three year degree in the minimum time and only 56 per cent completed such a degree in six years, using the 2010 cohort (South Africa's university pass rate shocker 2019). Completion rates for Dietetics students are higher; in the institution where this study was conducted, 56 per cent completed their four year degree in the minimum time and 65 per cent completed in six years over the last four years (Health Professions Council 
of South Africa (HPCSA) 2019), but this is still not satisfactory. The increasing emphasis on the recruitment of previously disadvantaged students often results in a significant change in the student landscape. Students from schools in rural areas need more academic support (McKenzie and Schweizer 2001), however, once settled into university life, these students sometimes perform better than their peers from urban schools because they had to learn to work independently even before they come to university (McKenzie and Schweizer 2001). Many students also have to learn in a language that is not their mother tongue, which places these students at an academic disadvantage (Van Rooy and Coetzee-Van Rooy 2015). Stress and stress-related burnout are increasing at an alarming rate amongst students (Eliot, Kolasa and Cuff 2018; Akgun and Ciarrochi 2003).

Although the factors mentioned above have an impact on all programmes offered at university, the factors for various programmes may differ due to the nature of the programmes. There is no literature specifically about the academic success of Dietetics students in South Africa and very little globally (Eliot et al. 2018; Palermo et al. 2009; Williams et al. 2012) and therefore there is a need for research in this field. The Dietetics programme, offered at ten South African universities, is viewed as challenging, especially due to the high volume of theoretical and practical work involved (HPCSA 2019). Dietetics courses in South Africa may not have the highest drop-out and minimum time completion rates $(16 \%$ and $71 \%$ respectively over the last four years for this institution), but the high workload, as in many other Health Sciences programmes, make it important that university officials, lecturing staff and curriculum developers understand what these barriers are and how to help students overcome them and adjust from high school to university life.

Although there is a paucity of recent literature on the matter in this specific field, much research has been done regarding general factors that can lead to study success (Chrisholm, Cobb, and Kotzan 1995; Mills et al. 2009; Ogude, Kilfoil, and Du Plessis 2012). According to Mills et al. (2009), the factor that has the most influence on the academic performance of first year students, and retention in Health Sciences, is their matriculation score, and especially mathematics and science matric marks (Swart and Becker 2014). It is also acknowledged that the poor level of education at secondary schools influences student success and retention rate in South African higher education (Council for Higher Education (CHE) 2013). Thus, in addition to offering higher education, universities have to bridge the school-university gap.

Other studies found that students who come from families that are better educated and financially stable, are more likely to succeed and persist with their studies, irrespective of their race or gender (Mills et al. 2009). Additionally, study skills influence academic performance and students with poor study habits are more likely to leave the university or to have adjustment 
problems in the transition from secondary school to university (McKenzie and Schweitzer 2001). Certain personality traits that have a positive effect on academic success include diligence, perseverance, passion, motivation and sociability, while personality traits such as laziness and emotional instability have a negative effect on academic performance (Komarraju et al. 2011; Strayhorn 2014; Liu and Hou 2018). According to Morisano et al. (2010), setting goals increases a student's enthusiasm, motivation and effort towards a given activity, which can lead to improved academic performance. Living at home or with family and friends can provide this support, depending on the situation (Bosman 2015), as well as outside interests such as hobbies (Chipas et al. 2012).

Factors with regard to the university environment become important in student success once the student is at university. According to a study done by Abisuga, Oshodi, and Babatunde (2015), the following general factors had the greatest influence on student academic success: the lecturing styles of lecturers, poor concentration by the students in class, lack of capable and effective lecturers, poor teaching material and stress as a result of a heavy workload.

Some of the major challenges that educators are faced with are the broader spectrums of student ability, learning and study skills, prior learning and varied educational goals that have to be included in the curriculum to suit an increasingly diverse student body. Due to the diversity in the quality of schooling and the readiness of students for university education, research on teaching and learning in higher education emphasizes the need for learner-centred teaching approaches, the critical importance of student-student interaction, active learning, prompt and detailed feedback, and the importance of taking diverse modes of learning into account (Macfadyen and Dawson 2010; Long, Ibrahim, and Kowang 2014). Educators also have to ensure that they do not cause information overload in students and that the staff and programmes are flexible and suited to students' needs. This becomes a time and energy consuming additional educational task for university lecturers, despite there being fewer staff members and resources available due to financial constraints imposed at universities (Gillespie et al. 2001). There is therefore less time to identify students with problems and work on remedial strategies. Reasons why students do not attend classes are often related to the lecturer and the lecturing style as well as reasons relating to the student as an individual (Moores, Birdi, and Higson 2019), but it is clear that there is a positive relationship between class attendance and academic success (Lukkarinen, Koivukangas, and Seppälä 2016). Therefore, lecturing staff need new strategies and resources to promote optimal and effective learning, encourage class attendance and to ensure early identification of at-risk students and devise ways of supporting their learning.

Peer support can assist students in addition to support from educators. Lorenzetti et al. 
(2019), found that the majority of students who participate in peer support programmes benefit from these programmes, not only academically, but also socially, psychologically and career wise. Peer support could be a successful solution, in a challenging programme, such as Dietetics.

The rest of this article will describe the initial exploratory phase of a programme to increase success and retention of BSc Dietetics students at a South African university. The aim of this initial study was to identify the key indicators of student success in order to plan effective intervention strategies to improve the academic success of the students. Though Dietetics is specific in certain ways as discussed above, the findings of this study can also serve to inform similar programmes in other university courses, where similar challenges are experienced, thereby aiding the general transformation of higher education and the improvement of quality across the board.

\section{METHODOLOGY}

An exploratory, descriptive, mainly quantitative method, with a qualitative component was used. The study started as a cross-sectional study of all students registered for Dietetics at one South African university from 2013 onwards and the exploratory phase ended in August 2019. It is envisioned that it will continue to develop into a longitudinal study, to test the effect of the intervention strategies identified in the initial study.

\section{Setting, population and sampling}

For this exploratory phase, all students in the Department of Dietetics of a South African university were used as the population.

In the first phase, institutional permission was obtained from the university to use the data in the Management Information System (MIS) of all BSc Dietetics students who registered from 2013 onwards in order to perform a statistical analysis of factors that may contribute to academic success (total number of students $=98$ ). In the second phase, in 2018, all 72 students present in the programme, from first to fourth year, were invited to participate in focus groups. A total of 19 students consented to participate in three focus groups of five to seven students per group. In the third phase, a questionnaire with open and close ended questions was used and all 28 students who started as first year students in 2019 were invited to complete the questionnaire. A total of 24 students consented and participated.

\section{Methodology}

Existing data from the university's MIS regarding matric results, student demographics and academic success in various modules were used to determine the progress of students. 
Correlational analyses were made with factors that predict academic success, as well as triangulating with existing literature on the topic. Student's t-tests were used to determine statistical significance. Where appropriate, ANOVAs and Cohen's d were used for comparisons and to determine practical significance.

The MIS data was then used to develop questions for focus group discussions to test students' perception of what factors determine academic success. Academic success was considered to be the passing of a module or programme. All Dietetics students were invited through posters and the electronic mail service to participate. The focus group discussions were held in a quiet place on campus, with no interference and no access to staff. The discussions lasted between two and two and a half hours. Data were thereafter transcribed, coded and themes were identified. An independent verifier verified the transcriptions.

The data from the MIS system and the focus groups were then used to develop a questionnaire to determine reasons for continuous class attendance, what students view as academic success, what students would like to get assistance with and to assess student perceptions of study skills classes and a buddy system that was put in place after the focus group discussions. First year students who did not participate in the focus group discussions, were invited to complete this questionnaire in 2019. A pilot study was done with three second year students who acted as advisors (called buddies) to the first year students in order to test the questionnaire. No changes had to be made to the questionnaire.

The ethical standards set out in the Belmont Report were upheld (World Medical Association 2013). Before commencement, the study was cleared by the ethics committee of the University (ethical clearance number H17-HEA-DIET-002). Institutional permission was obtained to use the MIS data. All students who volunteered to participate in the focus groups or who completed the questionnaire signed individual consent forms and each student's identity remained anonymous. No names or any source of identification was used in the study and any information shared during the focus group interviews remained confidential. All names were removed when the voice recordings were transcribed. No staff were involved in the focus group discussions.

\section{RESULTS AND DISCUSSION}

\section{Data from the MIS system}

The data from the MIS system concentrated on the academic achievement factor as part of overall academic success, as depicted in Figure 1 (York et al. 2015). The minimum requirement for students to enter the BSc Dietetics programme at this specific university is 60 per cent for 
Mathematics and Physical Science at National Senior Certificate level. Therefore, 60 per cent was chosen to separate students into the two groups for the MIS data analysis. Students were split into those who achieved less than 60 per cent in matric for Mathematics, Physical Science and Biology, and those who achieved 60 per cent or more. The average of these two groups in terms of the first year Nutrition and Chemistry modules and the second year Physiology module were then compared, as these are the subjects that many students do not pass on the first attempt. The results are shown in Table 1.

Table 1: Comparison between school and university results

\begin{tabular}{|c|c|c|c|c|c|c|c|c|c|}
\hline \multicolumn{2}{|c|}{ Maths } & \multirow{2}{*}{$\begin{array}{l}\mathbf{N} \\
18\end{array}$} & \multirow{2}{*}{$\begin{array}{l}\text { Mean } \\
63,67\end{array}$} & \multirow{2}{*}{$\begin{array}{c}\text { Standard } \\
\text { Deviation }\end{array}$} & \multirow{2}{*}{$\begin{array}{l}\begin{array}{l}\text { Std. } \\
\text { Error } \\
\text { Mean }\end{array} \\
2,83\end{array}$} & \multirow{3}{*}{$\begin{array}{c}\text { Student's t } \\
-1,21\end{array}$} & \multirow{3}{*}{$\begin{array}{l}\text { Df } \\
68\end{array}$} & \multirow{3}{*}{$\begin{array}{c}\text { p-value } \\
0,231\end{array}$} & \multirow{3}{*}{$\begin{array}{c}\text { Cohen's d } \\
\text { N/A }\end{array}$} \\
\hline \multirow{2}{*}{ DWN1111 } & $<60 \%$ & & & & & & & & \\
\hline & $>=60 \%$ & 52 & 67,92 & 13,15 & 1,82 & & & & \\
\hline \multirow{2}{*}{ CHGD $101^{2}$} & $<60 \%$ & 17 & 46,88 & 12,27 & 2,98 & \multirow{2}{*}{$-2,30$} & \multirow{2}{*}{64} & \multirow{2}{*}{0,025} & \multirow{2}{*}{$\begin{array}{c}0,65 \\
\text { (moderate) }\end{array}$} \\
\hline & $>=60 \%$ & 49 & 55,10 & 12,86 & 1,84 & & & & \\
\hline \multirow{2}{*}{ BSPD $211^{3}$} & $<60 \%$ & 15 & 51,53 & 9,68 & 2,50 & \multirow{2}{*}{$-1,86$} & \multirow{2}{*}{58} & \multirow{2}{*}{0,068} & \multirow{2}{*}{ N/A } \\
\hline & $>=60 \%$ & 45 & 57,56 & 11,21 & 1,67 & & & & \\
\hline \multicolumn{10}{|l|}{ Biology } \\
\hline \multirow{2}{*}{ DWN111 } & $<60 \%$ & 11 & 60,00 & 11,70 & 3,53 & \multirow{2}{*}{$-1,77$} & \multirow{2}{*}{63} & \multirow{2}{*}{0,082} & \multirow{2}{*}{ N/A } \\
\hline & $>=60 \%$ & 54 & 67,44 & 12,90 & 1,76 & & & & \\
\hline \multirow{2}{*}{ CHGD101 } & $<60 \%$ & 9 & 44,22 & 13,11 & 4,37 & \multirow{2}{*}{$-2,15$} & \multirow{2}{*}{58} & \multirow{2}{*}{0,036} & \multirow{2}{*}{$\begin{array}{c}0,78 \\
\text { (moderate) }\end{array}$} \\
\hline & $>=60 \%$ & 51 & 53,65 & 11,98 & 1,68 & & & & \\
\hline \multirow{2}{*}{ BSPD211 } & $<60 \%$ & 8 & 49,75 & 6,80 & 2,40 & \multirow{2}{*}{$-1,88$} & \multirow{2}{*}{53} & $0 \Omega 65$ & NA \\
\hline & $>=60 \%$ & 47 & 57,28 & 10,90 & 1,59 & & & 0,005 & IN/A \\
\hline Science & & & & & & & & & \\
\hline DYN111 & $<60 \%$ & 17 & 65,24 & 11,77 & 2,86 & 02 & 62 & 87 & No \\
\hline DVIVII & $>=60 \%$ & 47 & 66,47 & 13,36 & 1,95 & $-U, 34$ & 02 & 0,14 & $N / A$ \\
\hline CHCD101 & $<60 \%$ & 15 & 47,20 & 9,47 & 2,45 & $17+2$ & 50 & > & NA \\
\hline ועם שטחל & $>=60 \%$ & 45 & 53,40 & 12,89 & 1,92 & - & 50 & 0,09 & N $/ A$ \\
\hline RSPR211 & $<60 \%$ & 14 & 52,07 & 10,20 & 2,73 & 151 & 53 & 014 & $N / A$ \\
\hline 1 I & $>=60 \%$ & 41 & 57,41 & 11,80 & 1,84 & וזע, & 30 & 0,14 & $1 \mathrm{~N} / \mathrm{H}$ \\
\hline
\end{tabular}

${ }^{1} \mathrm{DWN}=$ Nutrition, ${ }^{2} \mathrm{CHGD}=$ Chemistry, ${ }^{3} \mathrm{BSPD}=$ Physiology

There were no significant differences between the two Mathematics groups and the Nutrition or Physiology results. However, those who achieved 60 per cent or more for Mathematics at school performed significantly better in Chemistry $(55.10 \%, \pm 12.86)$ compared to those who achieved less than 60 per cent $(\mathrm{p}=0.025$, with moderate practical significance). There was no significant difference between the two Biology groups and their Nutrition or Physiology results, but again, those who achieved 60 per cent or more for Biology performed better in Chemistry compared to those who achieved less than 60 per cent $(\mathrm{p}=0.04$ and moderate practical significance). No significant differences were found between the results of the two Physical Science groups. The results are in accordance with the findings of Mills et al. (2009) and Swart 
and Becker (2014) who indicated that Mathematics as a school subject is an indicator of success in the first year for first year Chemistry only, but differ from the findings of these authors in that it did not find that Physical Science is an indicator of success to the same degree. Other factors may therefore play a role in the lower pass rate of Nutrition and Physiology.

The average Admission Points Score (APS) of the students who entered the BSc Dietetics programme at this university since 2013 is 38.72. A one-way ANOVA was conducted to determine whether the average marks of the first year students were different for students who scored less than 38 points in the admission points score (APS), between 38 and 40 APS points or more than 40 APS points. A significant difference was found $(<0.004)$. The Tukey post hoc analysis revealed no significant difference between the first year averages of those with less than 38 APS points $(62.73 \% \pm 11.15)$ and those with between 38 and 40 APS points $(62.67 \%$ \pm 7.70 and $\mathrm{p}>0.05)$. However, those with more than 40 APS points had a significantly higher average than the other two groups $(70.00 \%, \pm 8.44$, with $p=0.01$ and $p=0.02$ respectively). The one-way ANOVA on the same three groups with second year results showed a statistically significant difference between these groups $(\mathrm{p}=0.04)$. However, the post hoc analysis did not reveal any significant results in the pairwise comparisons. These conflicting results could be due to the conservative nature of the post hoc tests and/or a lack of statistical power. The results can be seen as support for the view of York et al. (2015) that matric results are only one of the factors that determine the academic success of students.

There was a significant difference, with a large practical significance, between the first year averages of those who attended quintile one to three schools, compared to those who attended quintile four or five and private or international schools $(\mathrm{p}<0.005, \mathrm{~d}=1.57)$. This is summarised in Table 2. The same was true of the second year averages. Those who attended quintile four or five and private or international schools performed significantly better than those who attended quintile one to three schools $(\mathrm{p}<0.005, \mathrm{~d}=1.86)$. These results support the findings by Mills et al. (2009) that students from families that are better educated and financially stable, as students from quintile 4 and higher schools are likely to be, have a better chance of success than those coming from lower quintile schools. Schools in rural areas are usually also classified as quintile 3 or lower, with fewer resources, which may contribute to students not being fully prepared for higher education (McKenzie and Schweizer 2001). It should be noted that race was not one of the factors to determine success when the various types of schools were compared, as 16 of the 26 Black students (61.5\%) have attended quintile 4 and higher schools. Due to the low number of males in the BSc Dietetics programme, the differences in pass rates of males compared to females were not investigated in this study. 
Table 2: Comparison between university results of students who attended quintile one to three schools and other schools

\begin{tabular}{|c|c|c|c|c|c|c|c|c|c|}
\hline \multicolumn{2}{|c|}{ Quintile $^{1}(\mathbf{Q})$} & $\mathbf{N}$ & Mean & $\begin{array}{c}\text { Std. } \\
\text { Deviation }\end{array}$ & $\begin{array}{l}\text { Std. } \\
\text { Error }\end{array}$ & $\begin{array}{c}\text { Student's } \\
t\end{array}$ & Df & p-value & $\begin{array}{c}\text { Cohen's } \\
\text { d }\end{array}$ \\
\hline & Q1-3 & 10 & 54,85 & 5,11 & 1,62 & \multirow[b]{2}{*}{$-6,89$} & \multirow[b]{2}{*}{19,82} & \multirow[b]{2}{*}{$<0,005$} & \multirow[b]{2}{*}{1,57} \\
\hline & $\begin{array}{l}\text { Q4-5, Private } \\
\text { and } \\
\text { International }\end{array}$ & 62 & 68,54 & 9,118 & 1,16 & & & & \\
\hline \multirow{2}{*}{$\begin{array}{l}\text { 2nd } \\
\text { year } \\
\text { Average }\end{array}$} & Q1-3 & 8 & 50,19 & 5,89 & 2,08 & \multirow[b]{2}{*}{$-7,51$} & \multirow[b]{2}{*}{13,97} & \multirow[b]{2}{*}{$<0,005$} & \multirow[b]{2}{*}{1,86} \\
\hline & $\begin{array}{l}\text { Q4-5, Private } \\
\text { and } \\
\text { International }\end{array}$ & 59 & 68,88 & 10,47 & 1,36 & & & & \\
\hline
\end{tabular}

${ }^{1}$ The quintile system allocates all government schools into one of five categories, quintile 1 schools being the poorest. The classification is based on the rates of income, unemployment and illiteracy within the school's catchment area.

To determine the influence of the age at which students start with the BSc Dietetics programme, the students were split into those who started while 21 years old or younger and those who were older than 21 in the first year of study. The results are shown in Table 3.

Table 3: Comparison between students who were 21 years and younger and those who were older than 21 year in the first year of BSc Dietetics study

\begin{tabular}{|c|c|c|c|c|c|c|c|c|c|}
\hline \multicolumn{2}{|c|}{ Starting Age } & \multirow{2}{*}{$\begin{array}{l}\mathbf{N} \\
45\end{array}$} & \multirow{2}{*}{$\begin{array}{c}\text { Mean } \\
67,060\end{array}$} & \multirow{2}{*}{$\begin{array}{c}\begin{array}{c}\text { Std. } \\
\text { Deviation }\end{array} \\
8,6390\end{array}$} & \multirow{2}{*}{$\begin{array}{c}\begin{array}{c}\text { Std. } \\
\text { Error } \\
\text { Mean }\end{array} \\
1,2878\end{array}$} & \multirow{3}{*}{$\begin{array}{c}\mathbf{T} \\
0,840\end{array}$} & \multirow{3}{*}{$\begin{array}{c}\text { Df } \\
53,376\end{array}$} & \multirow{3}{*}{$\begin{array}{c}\text { p-value } \\
0,404\end{array}$} & \multirow{3}{*}{$\begin{array}{c}\begin{array}{c}\text { Cohen's } \\
\text { d }\end{array} \\
\text { N/A }\end{array}$} \\
\hline \multirow{2}{*}{$\begin{array}{l}\text { 1st year } \\
\text { Average }\end{array}$} & $\leq 21$ years & & & & & & & & \\
\hline & $>21$ years & 31 & 65,048 & 11,2356 & 2,0180 & & & & \\
\hline \multirow{2}{*}{$\begin{array}{l}\text { 2nd } \\
\text { year } \\
\text { Average }\end{array}$} & $\leq 21$ years & 42 & 68,03 & 10,198 & 1,574 & \multirow{2}{*}{1,415} & \multirow{2}{*}{47,627} & \multirow{2}{*}{0,164} & \multirow{2}{*}{ N/A } \\
\hline & $>21$ years & 28 & 63,84 & 13,257 & 2,505 & & & & \\
\hline
\end{tabular}

There was no statistically significant difference between the two groups. The average age of the students during the first year of study was 21.92 but there were only two students older than 25 years in their first year of study and therefore the results could not be compared with those of James, Krause and Jennings (2010), who found that students who are 25 years and older have increased academic performance compared to those between 19 and 24 years of age. This is attributed to older students having a higher work ethic and pre-determined goals, compared to the younger age groups (James et al. 2010, 68).

\section{Results from the focus group discussions}

The objective of the focus group discussions was not only to concentrate on academic achievement but on all aspects noted in Figure 1 (York 2015), except career success. Only the main themes that emerged from the discussions will be discussed here. Findings of this study corroborate existing literature on the topic of academic success. 


\section{Focus group question on what students see as success}

The first theme identified under this question was that students feel that success needs to be personalised according to the individual and their academic capability. One of the students stated that "I think it's like reaching your own full potential, so if my potential is $60 \%$ and I've reached $60 \%$ then that's my full potential ...". This was also noted in a study done by SarabiAsiabar et al. (2015) that mentioned that academic achievement cannot be generalised for all students. In addition, students mentioned that the attitude, behaviour and motivation of a student have great impact on academic success. Participants agreed with Strayhorn (2014) and Liu and Hou (2018), who found that having perseverance and passion is directly proportional to the amount of academic success a person can achieve and they concurred that a lack of motivation (intrinsic and extrinsic) results in a poor work performance and ultimately low academic grades. In addition, good time management skills, dedication and working hard were mentioned as factors that contribute to academic success. As one student put it,: "I think anybody can be successful if they are willing to put in what would be required of them, work hard and put time into it." This is supported by Komarraju et al. (2011) who stated that determination, diligence, motivation and being self-disciplined are just some of the traits required in order to be academically successful. Students also agreed with Morisano and co-workers (2010), who found that goals increase a student's enthusiasm, motivation and effort towards a given activity, which can lead to improved academic performance.

\section{Focus group question on whether high school prepare students well for university}

The majority of students mentioned that high school did not prepare them for university, as was also mentioned in the report of the CHE (2013). The workload at school was much less than at university and at school there was less independence. One of the students mentioned that: “... the workload in high school ... you would spend the whole semester doing four chapters then you come here you do four chapters in one day." Students also mentioned that very little practical skills are taught in school. When combining all these factors, it results in students becoming overwhelmed and not being able to easily transition from high school to university life.

\section{Focus group question on which high school subjects are important for success at university}

Participants in the focus groups agreed with the results of the analysis of the data on the MIS system and mentioned that school Mathematics and Physical Science were both important 
subjects that assisted students in creating a basis of knowledge for modules such as Chemistry and even Physiology and Biochemistry. This corresponds with the findings by Swart and Becker (2014). Students agreed that these should remain as pre-requisite subjects for the programme.

\section{Focus group question on what factors influence student success}

A pattern found among the participants was that living at home allowed them to have more time to focus on university, therefore allowing greater chance for academic success. They mentioned that having family or friends who can provide emotional support and assist with duties around the house relieves pressure. One of the students mentioned that: “... just that support is definitely something that has held me through this or just a hug ... when you [are] crying, because you can't do science (laughs) ... like you know your mom will have food for you, you have a safety net”. This is in agreement with Bosman (2015), who stated that succeeding academically cannot be done without support from families, friends and the academic institution.

It was also noted that having other interests that can reduce stress is key to academic success, in agreement with Shawwa et al. (2015) and Chipas et al. (2012). This can include hobbies such as reading or exercising, as well as social activities, such as spending time with friends and family. One of the students said: "I get involved in something, it relaxes me ... these different activities help me cool down from Dietetics and then I get the energy to go back to my books and study."

\section{Focus group question on what the Department of Dietetics can do to assist students to be successful}

The importance of university staff and the way in which they can contribute to student success was a strong theme in the focus group discussions. This was also noted by Abisuga et al. (2015). Participants noted that having unprepared lecturers or disorganized modules amounted to students becoming frustrated and stressed, resulting in a lack of concentration and confidence, which could lead to poor academic achievement. One student mentioned that "... having lecturers not being prepared then you can't be prepared yourself'. Participants agreed that having supportive, understanding and readily available staff has promoted academic success in the Department of Dietetics. Participants noted that it is encouraging for students to be able to discuss concerns, both academic and personal, with lecturers and have lecturers be understanding towards the situation they were facing. According to one student: “... with the majority of the lecturers, being able to email them and most of them reply within the same day and answer your question ... a lot of the lecturers are very open and understanding”. Long et al. 
(2014) found the same, namely that the relationship and the amount of interaction between the student and the lecturer is vital in ensuring high levels of student satisfaction and high levels of academic success. The participants also noted that they enjoy having lecturers who encourage participation and encourage students to ask questions in class.

\section{Results from the questionnaire answered by first years}

The results from the analysis of the questionnaire that was completed by first years in 2019 concur closely with the results of the focus group discussions in 2018. In the first part of the questionnaire, students could give multiple answers on why they come to class, as indicated in Table 4. Only 38 per cent of the students indicated that they always come to class, despite the fact that marks are given for class attendance due to the positive relationship between class attendance and academic success (Lukkarinen et al. 2016; Moores et al. 2019). Getting marks for attendance was important to students, as 88 per cent of the students answered that it is one of the reasons why they come to class.

The second important reason (79\%) was to learn more than what is just in the text book and to get clear explanations from lecturers. Students understood that education is not only about obtaining a degree, but that academic success also involves other factors that ensure holistic development, as indicated in the definition of York et al. (2015) in Figure 1. Other reasons for class attendance mentioned by Moores et al. (2019) were also given by students in the open-ended part of this questionnaire, such as attendance made it easier to study, participation in discussions (chosen by $38 \%$ as a reason), it is an opportunity to socialize, get ideas from others and learn from others.

One of the main reasons not to come to class was to catch up with other work and 42 per cent chose this option as a reason. Poor health, transport problems, the fact that students do not want to come to class if there is only one class scheduled for the day and that, if they are provided with the Power Point slides of the lecture, students would rather go through the lecture in their own time, were also mentioned as reasons why students do not come to class.

Table 4: Reasons for students to attend or not attend class

\begin{tabular}{|c|c|c|}
\hline $\begin{array}{l}\text { Reasons to come to class } \\
n=24\end{array}$ & Yes (\%) & No (\%) \\
\hline Because I get marks to come to class & $21(88)$ & $3(12)$ \\
\hline To learn more than what is in the text book and get explanations & $19(79)$ & $5(21)$ \\
\hline To participate in discussions & $9(38)$ & $15(62)$ \\
\hline So that my questions can be answered & $15(62)$ & $9(38)$ \\
\hline It is interesting to me and I want to know more & $15(62)$ & $9(38)$ \\
\hline To prepare for tests and examinations & $16(67)$ & $8(33)$ \\
\hline
\end{tabular}




\begin{tabular}{|l|c|c|}
\hline \multicolumn{1}{|c|}{$\begin{array}{c}\text { Reasons why I do not come to class } \\
\mathbf{n = 2 4}\end{array}$} & Yes (\%) & No (\%) \\
\hline Not applicable, I always come to class & $9(38)$ & $15(62)$ \\
\hline Have to catch up with other work, I am behind & $10(42)$ & $14(58)$ \\
\hline Classes are not interesting & $3(12)$ & $21(88)$ \\
\hline Lecturers are not well prepared or not good & $5(21)$ & $19(79)$ \\
\hline I am sometimes lazy & $7(29)$ & $17(71)$ \\
\hline I would rather be with my friends than in class & $0(0)$ & $24(100)$ \\
\hline
\end{tabular}

In addition to the study skills classes that are given to first year students during orientation and online study skills lectures, study skills classes were given to students as an intervention, as very few students attend the orientation sessions. Students can also ask for assistance from the Centre for Teaching, Learning and Media (CTLM), but few students make use of these opportunities. Students (67\%) agreed that these classes in the Department are necessary (67\%), but should not be compulsory. The reasons given for the need for such classes concur with reasons given in the literature (McKenzie and Schweitzer 2001; Mills et al. 2009; Abisuga et al. 2015; Eliot et al. 2018). The most important reason was that the classes assist them to prepare for tests and examinations ( $88 \%$ answered yes). Another reason was that the classes assist students to deal with academic stress (75\% answered yes), as was also mentioned by Akgun and Carriouchi (2003) and Eliot et al. (2018). Although only 46 per cent mentioned that the classes help them to manage the new university environment, some mentioned in the openended section of the questionnaire that they need assistance to adjust to life in the student residence.

In concurrence with the systematic review done by Lorenzetti et al. (2019), results showed that the buddy programme in the Department provides peer support that assists students with programme specific information, but also enrich the overall academic experience. Senior students could apply to be buddies and were paired according to their similarities and interests with first year students who wanted a buddy. Of the first year students, 54 per cent made use of the buddy system. In the open-ended section of the questionnaire, reasons given for making use of the system included that the buddy helped the students to understand the work, gave tips, guided them in the right direction, showed them what is expected and answered their questions. Buddies also gave students old test and examination papers, helped the first years to cope with the workload and to plan in advance and gain confidence.

For the students, academic success was to pass the module and progress to the next level. However, it was clear that the diversity and uniqueness of each student determine what is seen as success, as also mentioned by Sarabi-Asiabar et al. (2015). The full spectrum of academic success as shown in the definition of York et al. (2015) (Figure 1) was mentioned. Some aspects that were mentioned by the students were to achieve their specific goals and their full potential, 
to do well in order to help others, to put in effort and excel, to be professional and committed, because they gain self-confidence and because they love what they study.

Students were also asked to indicate what they expect from a lecturer. Three main themes emerged from the answers. Firstly, students want lecturers to have empathy, to be friendly and understanding. As also mentioned by Macfadyen and Dawson (2010), students want lecturers to acknowledge that they are individuals with diverse backgrounds. They want lecturers to believe in their students and to be willing to assist students. As mentioned by Abisuga et al. (2015), it is important to students that lecturers take the workload of students into consideration. It was also mentioned that lecturers should use simple English as only a third of the participants who answered the questionnaire spoke English as first language. This concurs with Van Rooy and Coetzee-Van Rooy (2015) who mentioned language as one of the most important barriers to success for students.

The second theme that emerged was that students want lecturers to be professional. Lecturers should be on time for class, well organised and have an excellent knowledge of their subject. They should be able to explain well and give good constructive feedback. Lastly, it is important to the students that the lecturer should have a passion for the subject, have a positive attitude, be enthusiastic about the work and have a high energy level. Most of these factors were also mentioned by Abisuga et al. (2015).

It is clear that students understand that they are also responsible for their own success, as mentioned by Olatunji et al. (2016). Their roles, as answered in an open-ended question, included to work hard every day, be diligent, ask questions or seek advice, prepare for class and revise and attend classes. Students mentioned that it is important to set goals, as mentioned by Morisano et al. (2010), and not to procrastinate. Students felt that they have a responsibility towards themselves too, they mentioned that it is important to them to balance academic and social life.

\section{CONCLUSION AND RECOMMENDATIONS}

Even though the high school system does not sufficiently prepare students for higher education, it is clear that it is necessary to keep to strict selection criteria for BSc Dietetics. Additional support is needed for students on an individual basis, especially for those from quintile one to three schools. Although a 60 per cent pass mark in Biology is not a pre-requisite for admission to BSc Dietetics at present, the significant difference in pass rate for the Chemistry module of students who have more than 60 per cent in matric in Biology indicate that this requirement should be considered in the future.

Students agreed with the results of the MIS analysis and their perceptions concurred with 
the literature. Most students had similar ideas and opinions regarding what academic success is, what promotes and deters success and what they as students, the university, the department and staff can do to promote success. Students indicated that reasons for academic success cannot be generalised but are personal according to the individual's learning style and capabilities and their individual idea of what academic success is. However, it was clear that not only academic support, but also social support is needed, especially for students who do not live with their families while studying. Students also indicated the importance of a balanced lifestyle.

Students realise their responsibility and understand the importance of good planning, of attending class and actively participating in the academic process in order to be successful, but that it is also important that the academic staff should be well prepared, experts in their field, have interest in and empathy for the students and be well organised. Support such as study skills classes and a buddy system should not be compulsory but does play an important role in guiding students towards success.

More research on the perceptions and the involvement of staff in actively guiding students towards success is needed. Other intervention strategies than the buddy system and study skills classes should also be investigated.

\section{LIMITATIONS}

As participation by students was voluntary in this study, the results may only reflect the opinion of students interested in study success. However, such a study cannot be made compulsory.

\section{ACKNOWLEDGEMENTS}

The authors would like to thank Kirstie Eastwood for assistance with the statistical analysis and the Siyaphumelela project co-ordinators for funding for the project.

\section{DECLARATIONS}

The authors certify that the article is their original work and has not previously been published and is not currently under consideration by another journal. The article does not, to the best of our knowledge, contain anything which is libellous, illegal or infringes anyone's copyright or other rights.

\section{REFERENCES}

Abisuga, O., O. Oshodi, and O. Babatunde. 2015. "Factors affecting students' academic performance in a building technology program in Nigeria." The International Journal of the Constructed Environment 6(2): 1-15. 
Akgun, S. and J. Ciarrochi. 2003. "Learned resourcefulness moderates the relationship between academic stress and academic performance." Educational Psychology 23(3): 287-294.

Bosman, A. 2015. "The relationship between student academic achievement and student learning styles in a multicultural senior school." Pretoria: UNISA (Doctorate in Education).

CHE see Council for Higher Education.

Chipas, A., D. Cordrey, D. Floyd, L. Grubbs, S. Miller, and B. Tyre. 2012. "Stress: Perceptions, manifestations and coping mechanisms of student registered nurse anesthetists." American Association of Nurse Anesthetists Journal 80(4): 49-55. https://pdfs.semanticscholar.org/ 28ab/95c2955219073a5cc9ae6913156b83334c0f.pdf. (Accessed 13 July 2018).

Chrisholm, M. A., H. Cobb, and J. A. Kotzan. 1995. "Significant factors for predicting academic success of first-year pharmacy students." American Journal of Pharmaceutical Education 59(4): 364-370.

Council for Higher Education. 2013. A proposal for undergraduate curriculum reform in South Africa: the case for a flexible curriculum structure. Pretoria: Council on Higher Education.

Eliot, K. A., K. M. Kolasa, and P. A. Cuffs. 2018. "Stress and burnout in nutrition and dietetics: Strengthening interprofessional ties." Nutrition Today 53(2): 63-67.

Gillespie, N. A., M. Walsh, A. H. Winefield, J. Dua, and C. Stough. 2001. "Occupational stress in universities: Staff perceptions of the causes, consequences and moderators of stress." Work \& Stress 15(1): 53-72. DOI:10.1080/02678370117944. (Accessed 20 November 2018).

Health Professions Council of South Africa. 2019. "Meeting of Heads of Departments with the Board of Nutrition and Dietetics." February, Johannesburg.

HPCSA see Health Professions Council of South Africa.

James, R., K. Krause, and C. Jennings. 2010. The first year experience in Australian universities. Canberra: Department of Education, Employment and Workplace Relations. ISBN: 9780734041661.

Komarraju, M., S. Karau, R. Schmeck, and A. Avdic. 2011. "The Big Five personality traits, learning styles and academic achievement." Personality and Individual Differences 51(4): 427-477. DOI: 10.1016.j.sbspro.2015.0.1021. (Accessed 15 March 2019).

Liu, Y. and S. Hou. 2018. "Potential reciprocal relationship between motivation and achievement: A longitudinal study." School Psychology International 39(1): 38-55.

Long, C. S., Z. Ibrahim, and T. O. Kowang. 2014. "An analysis on the relationship between lecturers' competencies and students' satisfaction." International Education Studies 7(1): 37-46.

Lorenzetti, D. L., L. Shipton, L. Nowell, M. Jacobsen, L. Lorenzetti, T. Clancy, and E. O. Paolucci. 2019. "A systematic review of graduate student peer mentorship in academia." Mentoring \& Tutoring: Partnership in Learning. DOI: 10.1080/13611267.2019.1686694. (Accessed 26 November 2019).

Lukkarinen, A., P. Koivukangas, and T. Seppälä. 2016. "Relationship between class attendance and student performance." Procedia - Social and Behavioural Sciences 228: 341-347. DOI: 10.1016/j.sbspro.2016.07.051. (Accessed 26 November 2019).

Macfadyen, L. P. and S. Dawson. 2010. 'Mining LMS data to develop an 'early warning system' for educators: A proof of concept." Computers and Education 54: 588-599. DOI:10.1016/j.compedu.2009.09.008. (Accessed 2 February 2017).

McKenzie, K. and R. Schweitzer. 2001. "Who Succeeds at University? Factors predicting academic performance in first year Australian university students." Higher Education Research \& Development 20(1): 21-33. DOI:10.1080/07924360120043621. (Accessed 12 February 2019).

Mills, C., J. Heyworth, L. Rosenwax, S. Carr, and M. Rosenberg. 2009. "Factors associated with the academic success of first year Health Science students." Advances in Health Sciences Education 14(2): 205-217. DOI 10.1007/s10459-008-9103-9. (Accessed 23 August 2017).

Moores, E., G. K. Birdi, and H. E. Higson. 2019. "Determinants of university students' attendance." Educational Research 61(4): 371-387. DOI:10.1080/00131881.2019.1660587. (Accessed 26 
November 2019).

Morisano, D., J. B. Hirsh, J. B. Peterson, R. O. Phil, and B. M. Shore. 2010. "Setting, elaborating and reflecting on personal goals improves academic performance." American Psychological Association 95(2): 255-264.

Ogude, N., W. Kilfoil, and G. du Plessis. 2012. "An institutional model for improving student retention and success at the University of Pretoria." The International Journal of the First Year in Higher Education 3(1): 21-34. DOI:10.5204/intjfyhe.v3i1.97. (Accessed 2 February 2017).

Olatunji, S. O., D. Aghimien, A. Oke, and E. Olushola. 2016. "Factors affecting performance of undergraduate students in construction related disciplines." Journal of Education and Practice 7(13): 55-62.

Palermo, C., K. Z. Walker, T. Brown, and M. Zogi. 2009. "How dietetics students like to learn: Implications for curriculum planners." Nutrition and Dietetics 66(2): 108-112.

Sarabi-Asiabar, A., M. Jafari, J. Sadeghifar, S. Tofighi, R. Zaboli, H. Peyman, M. Salimi, and L. Shams. 2015. "The relationship between learning style preferences and gender, educational major and status in first year medical students: A survey study from Iran." Iranian Red Crescent Medical Journal 17(1): 1-6. DOI: 10.5812/ircmj.18250. (Accessed 22 July 2018).

Shawwa, L., A. Abulaban, A. Abulaban, A. Merdad, S. Baghlaf, A. Algethami, J. Abbu-shanab, and A. Balkhoyor. 2015. "Factors potentially influencing academic performance among medical students." Advances in Medical Education and Practice 6: 65-75.

South Africa's University Pass Rate Shocker (Staff writer). 2019. "South Africa's university pass rate shocker." BusinessTech 13 November. https://businesstech.co.za/news/government/353575/ south-africas-university-pass-rate-shocker/. (Accessed 20 November 2019).

Stebleton, M. and K. Soria. 2013. "Breaking down barriers: Academic obstacles of first-generation students at research universities." Learning Assistance Review 17(2): 7-19.

Strayhorn, T. L. 2014. "What role does grit play in the academic success of black male collegians at predominantly white institutions?" Journal of African American Studies 18(1): 1-10.

Swart, O. and A. I. Becker. 2014. "Matric results in mathematics and languages: A predictor of undergraduate and postgraduate success." Progressio 36(1): 157-182.

Swartz, D. 2015. "NMMU's case for change." The Herald 26 October 2015. $\mathrm{http}: / /$ herald.newspaperdirect.com/epaper/iphone/homepage.aspx\#_article2af285a1-9f3c-4c3bb44c-8a2a48fd7348/waarticle2af285a1-9f3c-4c3b-b44c-8a2a48fd7348/2af285a1-9f3c-4c3bb44c-8a2a48fd7348//true. (Accessed 12 July 2018).

Van Rooy, B. and S. Coetzee-Van Rooy. 2015. "The language issue and academic performance at a South African University." Southern African Linguistics and Applied Language Studies 33(1): 3146.

Williams, B., T. Brown, and J. Etherington. 2012. "Learning styles of undergraduate nutrition and dietetics students." Journal of Allied Health 41(4): 170-176.

World Medical Association. 2013. WMA Declaration of Helsinki - Ethical principles for medical research involving human subjects. https://www.wma.net/policies-post/wma-declaration-ofhelsinki-ethical-principles-for-medical-research-involving-human-subjects. (Accessed 10 October 2017).

York, T., C. Gibson, and S. Rankin. 2015. "Defining and Measuring Academic Success." Practical Assessment, Research \& Evaluation 20(5): 1-20. 